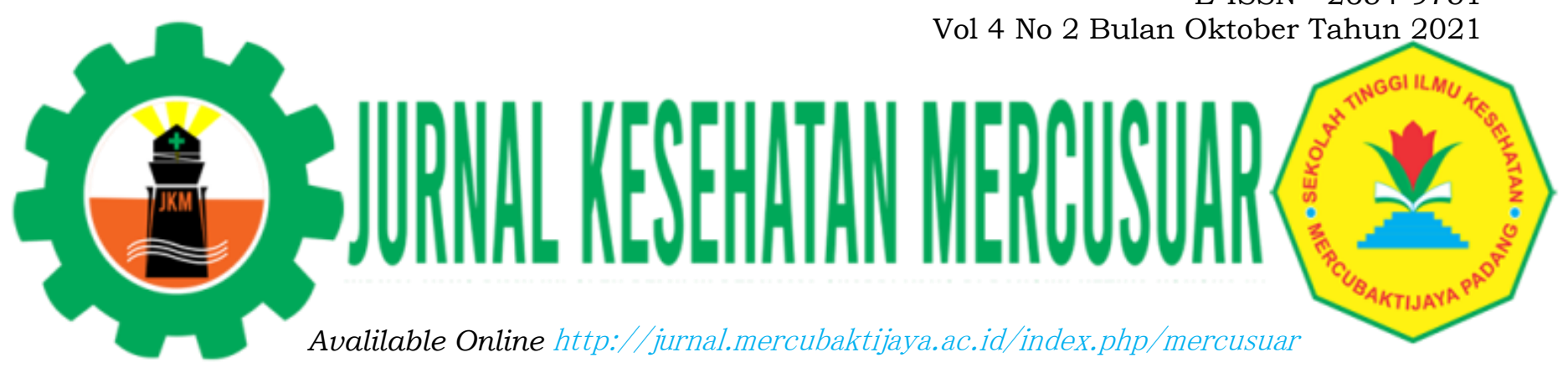

\title{
HUBUNGAN STATUS SPIRITUALITAS DENGAN KUALITAS HIDUP LANSIA Guslinda $^{1^{*}}$, Nurleny ${ }^{2}$, Nova Fridalni ${ }^{3}$, Yesi Martina ${ }^{4}$ ${ }^{1,2,3,4}$ STIKes MERCUBAKTIJAYA Padang \\ "email korespondensi : guslinda72@gmail.com
}

\begin{abstract}
Percentage of elderly population in the world in 2010 (13,5\%) prediction in 2025 increase became 14,9\% and in 2030 became 16,4\%. The quality of life of the elderly declines if it is not handled well and has a bad impact on their lives because it will be affected by several factors such as physical health, psychological such as spirituality. The purpose of this study is to find out the relationship between spirituality status and quality of life in elderly in Wisma Cinta Kasih Padang. The type of research is an analytical survey with a cross sectional approach that has been conducted at Wisma Cinta Kasih Padang on March 6th 2019 with population of 40 elderly and the total of samples are 40 elderly. The results of study is found that less than half (40\%) of respondents had fulfilled their spirituality status, less than half (45\%) of respondents had quality of life, and the relationship between spirituality status and quality of life in elderly people in Wisma Cinta Kasih Padang on 2019 ( $p$ value =0, 001). From the results of the study can be concluded that there is a relation between the quality of life of the elderly with the status of spirituality. So it is expected that health workers at Wisma Cinta Kasih Padang can improve the spirituality status of the elderly to improve the quality of life of them.
\end{abstract}

Keywords : Eldery; quality of life; spirituality status

\begin{abstract}
ABSTRAK
Persentase data jumlah penduduk lansia di dunia pada tahun 2010 adalah 13,5\% dan diprediksi jumlah ini pada tahun 2025 menjadi 14,9\%, dan pada tahun 2030 menjadi 16,4\%. Penurunan fisik dan psikologis dapat mengganggu spiritualitas dan berdampak pada kualitas hidup lansia. Kualitas hidup lansia menurun jika tidak di tangani dengan baik akan berdampak buruk untuk kehidupannya karena berpengaruh pada kesehatan fisik, psikologis dan spiritualitas. Tujuan penelitian ini adalah untuk mengetahui hubungan status spiritualitas dengan kualitas hidup pada lansia di wisma cinta kasih padang. Jenis penelitian survey analitik dengan pendekatan cross sectional study dilakukan di wisma cinta kasih padang pada tanggal 6 Maret 2019, dengan populasi 40 lansia dan dengan tekhnik pengambilan sapel total sampling. Hasil penelitian didapatkan kurang dari separoh $(40 \%)$ responden memiliki status spiritualitas terpenuhi dan kurang dari separoh (45\%) responden memiliki kualitas hidup berkualitas dan terdapatnya hubungan status spiritualitas dengan kualitas hidup pada lansia di wisma cinta kasih padang tahun 2019 ( $p$ value = 0, 001). Hasil penelitian dapat di simpulkan bahwa ada hubungan kualitas hidup lansia dengan status
\end{abstract}


spiritualitas. Diharapkan kepada tenaga kesehatan di wisma cinta kasih padang untuk dapat meningkatkan status spiritualitas lansia untuk meningkatkan kualitas hidup lansia.

Kata Kunci : Lansia; kualitas hidup; status spiritualitas

\section{PENDAHULUAN}

Menurut Cohen dan Lazarus (2012) kualitas hidup adalah tingkatan yang menggambarkan keunggulan seorang individu yang dapat dinilai dari kehidupan mereka. Kualitas hidup individu tersebut biasanya dapat dinilai dari kondisi fisiknya, psikologis, hubungan sosial dan lingkungannya (Kementerian Kesehatan RI, 2017).

Spiritual menurut kamus besar Bahasa Indonesia adalah sesuatu yang berhubungan dengan atau bersifat kejiwaan, rohani, batin. Spiritual berkenan dengan hati, jiwa, semangat, kepedulian antar sesama manusia, mahluk lain, dan alam sekitar berdasarkan keyakinan akan adanya Tuhan Yang Maha Esa (Yusuf, 2017).

Pada lansia kualitas hidup adalah suatu yang penting untuk kelangsungan hidupnya, maka jika kualitas hidup lansia menurun tidak di tangani dengan baik akan berdampak buruk untuk kehidupannya karena akan terpengaruh pada beberapa faktor seperti kesehatan fisik, psikologis seperti spiritualitas, hubungan sosial seperti umur, jenis kelamin, status perkawainan, pekerjaan dan tingkat pendidikan, dukungan keluarga (Hamzah, 2016).

Adapun faktor-faktor
mempengaruhi kualitas hidup lansia
menurut yaitu kesehatan fisik, ekonomi,
psikososial, gender atau jenis kelamin,
pendidikan, pekerjaan, pendapatan, asuransi
kesehatan, penyakit, spiritualitas pada lanjut
usia. (Pangkahila, 2014)

Hasil penelitian Ida Anggraini, dkk 2017 tentang Hubungan Antara Status
Spiritual Lansia Dengan kualitas hidup Lansia dengan hasil di dapatkan hubungan yang signifikan yang mengatakan bahwa aspek spiritual berperan penting sebagai tuntunan untuk kebiasaan hidup sehari-hari. Maka dapat disimpulkan bahwa kesehatan spiritual adalah rasa keharmonisan saling kedekatan antara diri dengan orang lain, alam, dan dengan kehidupan yang tertinggi (Angraini, Zulfitri, \& Novayelinda, 2018).

Hasil penelitian Munawarah (2018) tentang spiritualitas dengan kualitas hidup dengan hasil penelitian didapatkan dari 38 responden secara garis besar memiliki kualitas hidup baik dengan nilai rata-rata skor 97,39, nilai minimal dengan total skor 82 dan total skor maksimal 122, kualitas hidup merupakan sejauh mana seseorang dapat menikmati segala peristiwa yang dianggap penting didalam kehidupannya sehingga seseorang merasa kehidupannya menjadi sejahtera.

Data yang didapatkan dari wisma cinta kasih padang memiliki jumlah lansia pada tahun 2017 sebanyak 46 lansia dengan jumlah laki-laki 15 lansia dan perempuan 31 lansia sedangkan jumlah lansia pada tahun 2018 sebanyak 40 lansia.

Berdasarkan survey awal yang telah dilakukan pada lansia di Wisma Cinta Kasih Padang pada 10 orang lansia pada tanggal 24 November 2018, dilakukan wawancara dengan menggunakan kuisioner kualitas hidup WHOQOL-BREF dan yang mengatakan bahwa kepuasan dalam kualitas hidupnya biasa-biasa saja dan merasa sedikit menikmati hidup, sedangkan pada kuisioner spiritualitas yang digunakan pada peneltian Athurrita Choirru Ummah (Ummah, Warsito, \& Edi, 2016) 


\section{METODE PENELITIAN}

Penelitian ini merupakan jenis penelitian survey analitik dengan pendekatan cross sectional study (Notoatmodjo, 2017). Variabel independennya status spiritualitas dan variabel dependennya kualitas hidup lansia.

Populasi dalam penelitian ini berjumlah besar subjek yang mempunyai karakteristik tertentu (Notoatmodjo, 2017). Populasi dalam penelitian ini adalah semua lansia yang ada di Wisma Cinta Kasih Padang tahun 2019 sebanyak 40 lansia, sehingga jumlah sampel yang akan di teliti sebanyak 40 lansia dengan kriteria inklusi dan eklusi, yang mana kliteria inklusi yaitu bersedia menjadi responden, responden berada di tempat pada saat dilakukan penelitian, responden kooperatif.

Pengolahan data dilakukan dengan sistem komputerisasi dengan menggunakan uji Chi Square.

\section{HASIL DAN PEMBAHASAN}

\section{Gambaran Kualitas Hidup Lansia}

\section{Tabel 1. Distribusi Frekuensi Kualitas Hidup Lansia di Wisma Cinta Kasih Padang Tahun 2019}

\begin{tabular}{clcc}
\hline No & $\begin{array}{l}\text { Kualitas Hidup } \\
\text { Lansia }\end{array}$ & $\boldsymbol{F}$ & $\%$ \\
\hline 1. & $\begin{array}{l}\text { kurang } \\
\text { berkualitas }\end{array}$ & 22 & 55,0 \\
\hline 2. & Berkualitas & 18 & 45,0 \\
\hline & Total & $\mathbf{4 0}$ & $\mathbf{1 0 0}$ \\
\hline
\end{tabular}

Berdasarkan tabel 1 diatas terdapat lebih dari separuh $(55,0 \%)$ kualitas hidup lansia kurang berkualitas di Wisma Cinta Kasih Padang tahun 2019.

\section{Gambaran Status Spiritual Lansia} Tabel 2. Distribusi Frekuensi Status Spiritualitas di Wisma Cinta Kasih Padang Tahun 2019

\begin{tabular}{llll}
\hline No & $\begin{array}{c}\text { Status } \\
\text { Spiritualitas }\end{array}$ & $\boldsymbol{f}$ & $\mathbf{\%}$ \\
\hline 1. & $\begin{array}{l}\text { Spritualitas } \\
\text { tidak } \\
\text { terpenuhi }\end{array}$ & 24 & 60,0 \\
\hline 2. & $\begin{array}{l}\text { Spritualitas } \\
\text { terpenuhi }\end{array}$ & 16 & 40,0 \\
\hline & Total & $\mathbf{4 0}$ & $\mathbf{1 0 0}$ \\
\hline
\end{tabular}

Berdasarkan tabel 2 di atas didapatkan lebih dari separoh $(60,0 \%)$ status spritualitas lansia tidak terpenuhi.

\section{Hubungan Status Spiritual dengan Kualitas Hidup Lansia}

Tabel 3. Distribusi Frekuensi Status Spiritualitas di Wisma Cinta Kasih

\begin{tabular}{|c|c|c|c|c|c|}
\hline \multirow{5}{*}{$\begin{array}{l}\mathbf{N} \\
\mathbf{0}\end{array}$} & & \multicolumn{2}{|c|}{ Kualitas Hidup } & \multirow[b]{2}{*}{ Total } & \multirow{5}{*}{$\begin{array}{c}p \\
\text { value }\end{array}$} \\
\hline & Status & Kurang & Berkualit & & \\
\hline & Spritualitas & Berkualit & as & & \\
\hline & & as & & & \\
\hline & & $f$ & $\%$ & $\%$ & \\
\hline 1. & $\begin{array}{l}\text { spritualitas } \\
\text { tidak } \\
\text { terpenuhi }\end{array}$ & 1979,2 & 20,8 & 100 & \\
\hline 2. & $\begin{array}{l}\text { spritualitas } \\
\text { terpenuhi }\end{array}$ & $3 \quad 18,8$ & 1381,3 & 100 & 0,001 \\
\hline
\end{tabular}


Berdasarkan tabel 3 di atas dapat dilihat bahwa proporsi kualitas hidup lansia yang kurang berkualitas lebih banyak terdapat pada lansia dengan spritual yang tidak terpenuhi $(79,2 \%)$, dibandingkan dengan lansia yang memiliki spritual terpenuhi $(18,8 \%)$. Berdasarkan hasil uji chi-square didapatkan $\mathrm{p}$ value $=0,001(\mathrm{p} \leq 0,05)$, ada hubungan antara Status Spritualitas Dengan Kualitas Hidup Lansia di Wisma Cinta Kasih Padang Tahun 2019.

Kualitas hidup adalah kondisi fisik dan psikis yang mendukung kegiatan sehari-hari dalam kondisi sosial budaya tertentu. Kualitas hidup dapat dinilai apakah sangat baik, baik, sedang, atau kurang (Pangkahila, 2014).

Pada tahap usia lanjut, bayangan sering dominan mewarnai pearasaan spiritual. Keberhasilan kehidupan, ekonomi, agama, dan rasa berguna bagi orang lain dapat menjadi faktor penentu utama perasaan bahagia atau menderita. Dengan segala kamampuan yang sudah mulai menurun, ditambah bayangan kematian, maka penguatan penerapan spiritualitas untuk mempersiapkan masa akhir dengan damai harus dioptimalkan. Saat lanjut usia harus lebih banyak mendekatkan diri kepada sang pencipta, mensyukuri segala nikmat yang telah diperoleh, memperbanyak manfaat bagi orang lain dan meningkatkan upaya ritual kegamaan menjadi prioritas dalam pemenuhan kebutuhan spiritual (Yusuf, 2017).

Hasil penelitian ini didukung oleh penelitian Siti Munawarah (2018) tentang spiritualitas dengan kualitas hidup lansia dimana ada hubungan spiritualitas dengan kualitas hidup lansia ( $p$ value $=0,040$ ) (Munawarah, 2018).

Fenomena meningkatanya jumlah penduduk lansia menimbulkan permasalahan depresi, dimensia, gangguan konsep diri, gangguan tidur lanjut usia. Masalah tersebut jika tidak di tangani akan berkembang menjadi masalah yang komplek dari segi fisik, mental dan sosial yang berkaitan dengan kualitas hidup lansia. (Ma'rifatul Azizah, 2011)

Kualitas hidup adalah kondisi fisik dan psikis yang mendukung kegiatan seharihari dalam kondisi sosial buday tertentu. Kualitas hidup dapat dinilai apakah sangat baik, baik, sedang, atau kurang (Pangkahila, 2014).

Kualitas hidup terdapat beberapa dimensi. Yang pertama yaitu kondisi fisik. Dimensi kondisi fisik ini fokus pada aspek kesehatan. Beberapa aspek spesifik dalam dimensi ini seperti kebugaran, mobilitas, dan keamanan personal. Yang kedua kesejahteraan sosial, dua dimensi utama dalam kesejahteraan sosial adalah dimensi hubungan interpersonal dan keterlibatan dalam masyarakat. Yang ke tiga Kesejahteraan emosional dimensi ini terdiri dari beberapa aspek seperti status atau respek, kesehatan mental, stres, seksualitas, pemenuhan kebutuhan, dan kepercayaan diri (Rasjidi, 2010). Yang ke empat Spiritualitas yang Spiritualitas dapat didefinisikan sebagai hubungan personal dengan sosok transeden. spiritualitas mencakup idealisme, sikap, pemikiran, perasaan dan pengharapan terhadap Yang Maha Esa. (Afnesta Yuzefo, Sabrian, \& Novayelinda, 2015).

\section{SIMPULAN}

Bahwa lebih dari separoh $(55,0 \%)$ responden memiliki kualitas hidup kurang berkualitas dan lebih dari separoh $(60,0 \%)$ responden memiliki status spiritualitas tidak terpenuhi. Maka terdapat hubungan status spiritualitas dengan kualitas hidup pada 
lansia di wisma cinta kasih padang tahun $2019(p=0,001)$.

\section{UCAPAN TERIMAKASIH}

Peneliti mengucapkan terimakasih kepada semua pihak yang sudah mendukung dalam penyelesaian penelitian ini khusus nya kepada kepala Wisma Cinta Kasih Padang yang telah memberikan izin kepada peneliti untuk melakukan penelitian.

\section{DAFTAR PUSTAKA}

Afnesta Yuzefo, M., Sabrian, F., \& Novayelinda, R. (2015). Hubungan Antara Status Spiritual Lansia Dengan Gaya Hidup Lansia. JOM, 2(2).

Angraini, I., Zulfitri, R., \& Novayelinda, R. (2018). Hubungan Antara Status Spiritual Lansia Dengan Gaya Hidup Lansia. Universitas Riau.

Hamzah, R. (2016). Hubungan Usia Dan Jenis Kelamin Dengan Kualitas Hidup Pada Penderita Gagal Jantung Di RS. PKU Muhammadiyah. Yogyakarta: Universitas Aisyiyah Yogyakarta.

Kementerian Kesehatan RI. (2017). Analisis Kesehatan Lansia. Jakarta.

Ma'rifatul Azizah, L. (2011). Keperawatan Lanjut Usia. Yogyakarta: Graha Ilmu.

Munawarah, S. (2018). Spiritualitas dengan Kualitas Hidup Lansia. Nerspedia Journal, 1(1).

Notoatmodjo, S. (2017). Metodologi Penelitian Kesehatan. Jakarta: Rineka Cipta.

Pangkahila, W. (2014). Seks Dan Kualitas Hidup. Kompas.

Rasjidi, I. (2010). Perawatan Paliatif dan Bebas Nyeri pada Kanker. Jakarta: Sagung Seto.
Ummah, A. C., Warsito, \& Edi, B. (2016). Hubungan Kebutuhan Spiritualitas Dengan Kualitas Hidup Pada Lansia Di Panti Wreda Kota Semarang. Universitas Diponegoro Semarang.

Yusuf. (2017). Kebutuhan Spiritual Konsep dan Aplikasi dalam Asuhan Keperawatan. Jakarta: Mitra Wacana Media. 